\title{
Effectiveness of Information Communication Technology Integration on Teaching and Learning in Public Secondary Schools in Mwanza, Tanzania: A Case of Misungwi District
}

\author{
Dongo Nzori Dongo, Demetria Gerold Mkulu
}

\begin{abstract}
Department of Educational Foundation, St. Augustine University of Tanzania, Mwanza, Tanzania.
Received: 20 Nov 2021; Received in revised form: 30 Dec 2021; Accepted: 10 Jan 2022

(C2022 The Author(s). Published by TheShillonga. This is an open access article under the CC BY license (https://creativecommons.org/licenses/by/4.0/)
\end{abstract}

\begin{abstract}
The main purpose of this study was to examine the effectiveness of ICT integration on effective teaching and learning process in public secondary schools found in Misungwi district. The study employed mixed research approach and the convergent parallel design for data collection. The study targeted 8087 respondents which comprised 7760 students, 24 school heads, 300 secondary school teachers and 3 district education officers and used 100 respondents as a sample size. The study employed simple random, stratified and purposive sampling to select respondents and the data collection tools were questionnaires, interview and observation. The study revealed that implementation of ICT has many influences on effective teaching and learning process such as it enhances the accessibility of teaching and learning materials, improve teachers and students knowledge and skills and makes lesson more effective, makes student-centered and self-directed, makes and creative good teaching and learning environment, and improve high thinking capacity for students and teachers. The study recommended that ICT infrastructures such as computers and other ICT resources should be adequately provided, and secondary schools leaders should establish income generating projects to increase sources of funds, in-service training to teachers must be provided, as well as special programs on ICT should be provided to boost teachers experience and familiarity on the use of ICT in teaching and learning process.
\end{abstract}

Keywords - ICT, teaching and learning processes, public secondary schools.

\section{I. \\ INTRODUCTION AND BACKGROUND TO THE STUDY}

Technology is viewed as a vibrant component in teaching and learning in the $21^{\text {st }}$ era (Paschal, and Mkulu, 2020). The growing usage of technology in teaching and learning has developed from traditional to the most flexible methods, (Sun and Chen, 2016). From the above standing point, Paschal and Mkulu (2020) have emphasized that the application of technology in education has influenced virtual learning, distance learning, cooperative learning and machine learning. This can be the major reason why the application of ICTs in schools are getting critical attention day after day from different education stakeholders such as parents, teachers, community, donors and international organizations at large. UNESCO (2015) has asserted that the practice of ICT in the development of teaching and learning has continued to grow steadily all over the countries since the beginning of the $21^{\text {st }}$ century. ICTs have a great impact on peoples' life across the globe as it has transformed the approach on how people reason, how they perform their work and how they live (Grabe, 2007). In this technological century, the effectiveness of teaching and learning process depends on how ICT has been in cooperated into the provision of education (Ghaviefekr, Afahar \& Amla, 2012).

Kamal and Qureshi (2009) have shown that ICT can be used as an instrument for achieving economic change in every country as well as the achievement of all the 17 United Nations Sustainable Development Goals (SDGs). According to UNDPHDR (2001), most of the emerging countries including Malaysia, Singapore, Brazil, China, India, Indonesia, South Africa, as well as Tunisia, among others are active in the use of new technology in almost all of their developmental sectors. Countries that have recorded a significant economic improvement in the world are those 
that have considerable initiatives in ICT integration in all sectors especially in education systems.

African countries have been working hard to integrate ICTs in their education systems. However there a lot of challenges to the effectiveness of this integration like slow internet connection, scarce technological resources, language barrier, as well as poor technological know-how which has created the digital divide between developed countries and the developing countries (Kamal et al, 2009). For instance, Botswana has shown an effort in the use of ICTs in education by dedicating most of its financial budget to strengthen the technological infrastructures so as to support an effective use of ICT in educational (Isaacs, 2007; Mangesi, 2007). In line with this, Kenya has also initiated National ICT Policy in 2006 that focused on values and strategies for the use of ICTs to improve the Kenya's livelihood. The ICT policy in Kenya gives a chance for establishment of strong ICT infrastructures for development of the country (MOEST, 2006). Also, Kenya Education Sector Support Program (KESSP) and other agencies that collaborate with MOEST like USAID has supported the improvement of the quality education in primary and secondary schools through effective use of ICT in school setting.

The Tanzania Education and Training Policy of 1995 and that of 2014 (Education and Training Policy) have directed the use of ICT in teaching and learning process in all levels of education. Again, National Information and Communication Technology Policy of 2016 and the National Vision reports guided by the Tanzania Development Vision of 2025, have identifies that ICT is central to a competitive social and economic change. Therefore, Integration of ICT in education was seen as the best strategy toward the realization of national development (NICTP, 2016; Chapelle, 2011). It is from this situation that the researcher was interested in studying the effectiveness of ICT integration on teaching and learning process in public secondary schools in Misungwi district.

\subsection{Statement of the Problem}

In recent years, ICT integration in all developmental sectors has been increasing in both developing and developed countries (Mangesi, 2007; Hermans, Tonduer, Van and Valke, 2008). In school contexts, ICT is viewed as the main constituents in changing the country to the future development and supporting teachers with the global necessities to exchange traditional teaching and learning methods (Ghavifekr and Rosdy, 2015). With that standing point, teaching and learning in school setting has been using ICT as the heart of instructional development (Ayoub, 2014; Alcardo et al., 2015). In connection to that, Luhamya, Bakkabulindi and Mayinda (2017) noted that the ICT integration on classroom setting becomes almost powerful when learning environments and supports learners to deal with knowledge in active, self-directed and constructive ways. In Tanzania like any other developing countries, there has been an increasing efforts made by educational institutions and the government in the adoption and integration of ICT in education as the key force to attain the teaching and learning goals Alcardo et al,(2015);. However, the review of literature such as Ayoub (2014); Alcardo et al,(2015); Placidius (2014) have indicated that, the efforts made, the adoption, implementation and integration of ICT in education are not effective to enable educational institutions to meet the intended goals and to attain development in the country. Hence, this study aimed at examining the ICT integration its effectiveness on teaching and learning processes in public secondary schools in Misungwi District with the hope of awakening the majority educational stakeholders to effectively implement radical and positive changes that will help in integration and development of the effective use of ICT in teaching and learning development in Misungwi district and Tanzania as whole.

\subsection{Objectives of the Study}

i. To assess the influence of Information Communication Technology facilities on effective teaching and learning processes in public secondary schools in Misungwi District.

\subsection{Research Question}

The study was strived to address the following question:

i. What is the influence of Information Communication Technology facilities on effective teaching and learning processes in public secondary schools in Misungwi District?

\subsection{Significance of the Study}

The findings of the study may deliver necessary data to the government, researchers as well as other education stakeholders to solve the challenges facing public secondary schools on the implementation of ICTs on teaching and learning process. Over this study, the findings may assist educational planners and policy makers to formulate appropriate ICT policies for teachers training colleges and universities that will equip students who are prepared to be teachers with ICTs knowledge and skills which will facilitate their capability of integrating ICT in their teaching process effective learning process. In addition, findings of the study are important to educational administrators such as regional and District educational officers to determine the challenges facing public secondary schools on the use of ICTs in education so they can help to find mitigation measures to overcome those problems. Furthermore, Study 
findings are important to the community and other education stakeholders in such a way that it helps them to understand their role in education and how they can be more supportive in the expansion of ICT infrastructures in public secondary schools.

\section{LITERATURE REVIEW}

\subsection{Theoretical Literature Review}

The study was guided by the Constructivism learning theory developed by Jean Piaget in 1972 and Lev Vygotsky in 1978. The theory elucidates how individuals, especially students, attain knowledge and skills through interaction with various activities. Constructivism learning theory proposes that individuals can build knowledge and meaning from their experiences as they connect with the reality or others with different viewpoints. Constructivism theory relates to the study in such a way, it emphasizes students in assimilation and interaction of various ways such as ICT on finding knowledge and skills. Therefore, both teachers and learners in public secondary schools utilize ICT facilities like computer, smart phone and internet services on accessing learning materials which enrich teaching and learning process.

\subsection{Empirical Literature Review}

\section{The Influence of ICT facilities on Effective Teaching and Learning Process}

ICT integration remains significant in secondary schools for teachers and learners during the teaching and learning process. ICTs facilities influence teachers to access teaching resources across the globe online for the aim of enhancing their teaching and learning process. As far as this notion is concerned, various studies which have been conducted have indicate that ICT facilities has a progressive effect on the education development. Particularly, the studies conducted by Ghavifekr and Rosdy (2015) in Malaysia; Demici (2009) in Turkey; Teo (2008) in Singapore; Malakia and Clonera (2018) in Namibia and) and Placidius (2014) in Tanzania.

The findings of a study conducted in Singapore by Teo (2008) was similar to what was discovered in Namibia by Malakia and Clonera (2018) who conducted study on teachers' perception on the use of ICTs in secondary schools. The researchers have discovered that teachers have positive insights towards ICTs application in school settings. They also reveal that ICT facilities have a positive influence on the effectiveness of teaching and learning process. They then recommended that the government through the Ministry of education should certify procedures of equipping teachers with the required knowledge and skills for the adoption of modern ICT resources in education.
In Tanzania, Placidius (2014) conducted a study on teachers' readiness towards the use of ICT as a pedagogical tool in secondary schools. Findings discovered that teachers had positive outlooks towards the application of ICT as a pedagogical device although the integration of ICTs in their teaching and learning process is still problem because of different obstacles. Again, Alcardo et al,(2015) explored secondary schools students' skills and attitudes on effective use of ICTs in Tanzania. The study has discovered that students' ICTs skills were moderate and ICT facilities had not been utilized fully for teaching and learning processes in public schools. The study has also discovered that if the ICT will be fully integrated in teaching and learning, it will help to make teachers and their students to be global, by being able to connect with other educational stakeholders across borders. This is due to the fact that, ICT facilities helps students to search new knowledge, learn effectively, and also improve their knowledge and skills on the use of education technology.

\subsection{Knowledge Gap}

Most of reviewed studies was conducted in countries outside Tanzania like that of Malakia and Clonera (2018) in Namibia; Teo (2008) in Singapore; Laaria (2013) in Kenya; Demici (2009) in Turkey and Ghavifekr and Rosdy (2015) in Malaysia. The topic is not much documented in Tanzania so this study was conducted in Tanzania to fill the gap. Also, most of the studies reviewed studies have used single research approach, and most of them used questionnaires and interview guide for data collection. This study has used mixed research approach and also observation schedule, interview guide and questionnaires have been used for data collection. Again, most of the reviewed literatures are studies conducted many years ago, then this study will fill time gap as it conducted in 2021 so new knowledge have been discovered.

\section{RESEARCH DESIGN AND METHODOLOGY}

\subsection{Research Approach}

The study used a mixed research approach whereby quantitative and qualitative research approaches were employed in a single study (Williams, 2007; Creswell, 2011). The current study employed convergent parallel design whereby the researcher collected qualitative and quantitative data concurrently (Kothari, 2004; Bryman \& Bell, 2007; Sweeney, 2016). Population is a group of either individuals or items that the researcher wishes to take the sample of the study (Bryman, 2008). The study involved a target population of 8087 individuals and a sample size of 100 respondents in which 64 were students, 5 heads of schools, 30 teachers, and one District Education Officer. 
Simple random sampling was used to select students, purposive sampling was used to select heads of schools and district education officer, and lastly, stratified simple random sampling was used to select teachers (Mugenda and Mugenda, 2003; Stephanie, 2003).

Data was collected using questionnaires, interview guide, and observation schedule. Questionnaires involved a series of questions printed where the respondents replied the questions on their own (Kothari, 2004). This instrument was used to collect data from students and teachers. Interview guide is a series of questions managed by the researcher, and it involved a face to face conversation between researcher and participants (Kothari, 2014; Creswell, 2014). It was used to collect data from heads of schools and the district educational officer. Observation Schedule is the method of gathering data through visiting the intended area of study and mark some intended physical characteristics in the natural setting (Patton, 2002). The researcher note-taking to record the availability of ICT facilities and various documents needed for the study. Content validity of the instruments was checked by different people who are knowledgeable in research issues (Mugenda and Mugenda, 2003). Split half technique was used to check the reliability of the research instruments where a correlation coefficient of 0.94 was obtained which indicated that the instruments had a high degree of reliability Kombo and Tromp (2006; Muchiri, 2012). Both qualitative and quantitative data were collected simultaneously. Quantitative data obtained from the questionnaires was analyzed using a Statistical Package

Table 4.1 Students Responses on the Influences of ICT on Teaching and Learning Process (n=64) for Social Science (SPSS) Version 23.0. Researcher presented qualitative data through percentages, tables and charts. Qualitative data obtained from open-ended questions and interviews guide was analyzed using open coding, categories and themes. Data are presented using explanation and quotations of direct words from the participants

The researcher followed all acceptable research ethical principles as articulated in many literatures and scholars. Permission letter for data collection was collected from the authority, guaranteed secrecy of information given by respondents, anonymity, discretion and safety of the respondents. Finally, the researcher acknowledged all the literatures used by adhered to American Psychological Association (APA) Manual, Sixth edition.

\section{DATA ANALYSIS AND DISCUSSION OF THE FINDINGS}

\subsection{The Influence of ICT Facilities on Effective Teaching and Learning Process}

The researcher was intended to discover the influence of ICT facilities on effective teaching and learning processes in public schools. In a likert scale question, teachers and students were asked to rate their position about the stated influence of ICT facilities on effective teaching and learning processes. The rating scale was 1-Strongly Disagree; 2Disagree; 3-Moderate; 4-Agree; 5-Strongly Agree. Students' responses are presented in table 4.1

\begin{tabular}{|c|c|c|c|c|c|}
\hline \multirow[t]{2}{*}{ Influences } & \multicolumn{5}{|c|}{ Frequency (Percent) } \\
\hline & 1 & 2 & 3 & 4 & 5 \\
\hline Computer in teaching and learning makes lesson more effective & $0(0.0)$ & $2(3.1)$ & $7(10.9)$ & $19(29.7)$ & $36(56.3)$ \\
\hline Smartphone in teaching and learning makes lesson more effective & $5(7.8)$ & $4(6.3)$ & $15(23.4)$ & $16(25.0)$ & $24(37.5)$ \\
\hline Power point presentation stimulate teaching and learning process & $1(1.6)$ & $3(4.7)$ & $13(20.3)$ & $22(34.4)$ & $25(39.1)$ \\
\hline $\begin{array}{l}\text { Digital divide influences learning methods and modes of } \\
\text { instructions }\end{array}$ & $0(0.0)$ & $3(4.7)$ & $4(6.3)$ & $27(42.2)$ & $30(46.9)$ \\
\hline ICT based teaching and learning improves academic excellence & $0(0.0)$ & $1(1.6)$ & $11(17.2)$ & $19(29.7)$ & $33(51.6)$ \\
\hline $\begin{array}{l}\text { Internet sources improve accessibility of learning in the } \\
\text { classroom }\end{array}$ & $3(4.7)$ & $5(7.8)$ & 19(29.7) & $21(32.8)$ & $16(25.0)$ \\
\hline
\end{tabular}

Source: Questionnaire data (2021)

Table 4.1 shows that 56.3 percent of the participants have strongly agreed that ICT facilities such as computers make the lesson more effective, 29.7 percent agreed, 10.9 were moderate and only 3.1 percent disagreed. Findings revealed that majority of participants (86.0 percent) who were involved in the study agreed that using ICT facilities such as computers during teaching and learning in public secondary schools makes the lesson more effective.

In addition to that, one of interviewee had this to say:

Computers and projectors are very significant tools in teaching and learning process. In this case, we give 
an emphasis to heads of schools to buy at least one or two computers in their schools. These facilities have many influences, as they enhance them with some additional teaching and learning resources which are not available at schools, and also they use them in matters concerning the schools administration (Interviewee F, September 2021)

The findings come in line with the study done by Teo (2008) who discovered that ICT helps in the progression in improving teaching and learning process and the provision of quality teaching. The availability of ICTs facilities and its integration in education should be kept in high consideration in our schools by all education stakeholders.

Furthermore Table 4.1 shows that 37.5 percent strongly agreed that ICT facilities such as smart phones make the lesson more effective, 25.0 percent agreed, 23.4 percent were moderate and 14.1 disagreed. These findings indicate that majority of participants (85.9 percent) agreed that using smart phones in teaching and learning processes facilitate and make the lesson more effective in schools.

In addition, Table 4.1 shows that 39.1 percent have strongly agreed that the use of PowerPoint presentation during the teaching and learning in classroom facilitates teaching and learning process, 34.4 percent agreed, 20.3 percent were moderate and 6.3 percent disagreed. The study findings revealed that majority of participants (73.5 percent) have agreed that practice of using PowerPoint presentations in the classroom facilitates the teaching and learning process. PowerPoint presentation during the teaching is a very important in teaching and learning process because it motivates and makes the lesson attractive to students.

In an interview, one interviewee was quoted commenting that;

I am a head of school but sometimes I teach in class. So my observation is that using PowerPoint in teaching is a very helpful teaching facility because it allows students to be able to see the lesson notes on the board. In our school here, teachers use to waste a lot of time writing notes on the board by hand; so my advice is that the government of Tanzania shoul ensures that ICT facilities ae available in schools and teachers must be trained on how to operate ICT machinery (Interviewee G, Sept. 2021).

Likewise, Table 4.1 shows that 46.9 percent of the respondents strongly agreed that digital divide influences change in teaching and learning methods as well as modes of instructions, 42.2 percent agreed, 6.3 percent were moderate and 4.7 percent were disagreed that the practice of usability of digital divide in schools influences the changes in teaching and learning methods and modes of instructions during the teaching and learning process. Thus, based on the findings, 89.1 percent of participants agreed that the use of digital divide in public secondary schools during the teaching and learning influences and changes the learning methods as well as modes of instructions to students.

Also, Table 4.1 shows that 81.3 percent agreed that ICT based teaching and learning improves students' academic excellence in public secondary schools, 17.2 percent were moderate and only 1.6 percent disagreed with the statement. These findings give a picture that ICT based has an influence in teaching and learning process and improves students' academic performance as articulated by majority of participants (81.3 percent).

This outcome is similar to what was discovered by Clonera (2018) who conducted study on teachers' perception on the use of ICTs in secondary schools. The researchers have discovered that teachers have positive insights towards ICTs application in school settings. They also reveal that ICT facilities have a positive influence on the effectiveness of teaching and learning process. When ICT facilities are used in teaching and learning process, they help to simplify the understanding of students and hence, help to ensure that the learning goals are achieved in time. The researcher has then recommended that the government through the Ministry of education should certify procedures of equipping teachers with the required knowledge and skills for the adoption of modern ICT resources in education.

Furthermore, Table 4.1 shows that 25.0 percent of participants has strongly agreed that availability of internet service in school environments improves the accessibility of more teaching and learning materials, 32.8 percent agreed, 29.7 percent were moderate and only 12.5 percent of participants disagreed with the statement. Based on these findings, 57.8 percent agreed that internet service in school environments is very important and improves the accessibility of teaching and learning resources which facilitate teaching and learning process for teachers and students in secondary schools in Tanzania specifically in Misungwi district.

These findings clarified by one of interviewee from secondary school B during an interview, who said that;

Yes, it is the responsibility of educational stakeholders in the higher level of education and who are in collaboration with mobile phone companies to insist them to improve their internet service 
around public secondary schools like here in our school. When internet service around schools are improved, it enhances the usage and accessibility of teaching and learning materials by using either computer or smart phones (Interviewee B, September 2021)

When researcher interviewed one of the participants concerning influence of ICT integration on effective teaching and learning in his school, interviewee had this to say;

Indeed, our school has a special room for computers. This room has many influences not only for teachers but also for students because they always come here to learn computer skills and also for searching educational materials on the internet. Teachers and students use this special room to access teaching and learning resources such as books and others online (Interviewee C, September, 2021)

These findings correspond to the study conducted by Ghavifekr and Rosdy (2015) who showed that ICT facilities integration in education sectors has a great influence in teaching and learning process and teachers' professional development for quality teaching and learning process in Malaysia.

Furthermore, the same question was asked to teachers and the rating scale was again 1-Strongly Disagree; 2-Disagree; 3-Moderate; 4-Agree; 5-Strongly Agree. Teachers' responses are presented in table 4.2:

Table 4.2 Secondary School Teachers Responses on the Influences of ICT on Teaching and Learning Process (n=26)

\begin{tabular}{|c|c|c|c|c|c|}
\hline \multirow[t]{2}{*}{ Influences } & \multicolumn{5}{|c|}{ Frequency (Percent) } \\
\hline & 1 & 2 & 3 & 4 & 5 \\
\hline Computer in teaching and learning makes lesson more effective & $0(0.0)$ & $0(0.0)$ & $3(11.5)$ & $13(50.0)$ & $10(38.5)$ \\
\hline Smartphone in teaching and learning makes lesson more effective & $4(15.4)$ & $0(0.0)$ & $4(15.4)$ & $11(42.3)$ & $7(26.9)$ \\
\hline Power point presentation stimulate teaching and learning process & $0(0.0)$ & $0(0.0)$ & $3(11.5)$ & $9(34.6)$ & $14(53.8)$ \\
\hline $\begin{array}{l}\text { Digital divide influences learning methods and modes of } \\
\text { instructions }\end{array}$ & $1(3.8)$ & $4(15.4)$ & $1(3.8)$ & $10(38.5)$ & $10(38.5)$ \\
\hline ICT based teaching and learning improves academic excellence & $0(0.0)$ & $0(0.0)$ & $5(19.2)$ & $5(19.2)$ & $16(61.5)$ \\
\hline $\begin{array}{l}\text { Internet sources improve accessibility of learning in the } \\
\text { classroom }\end{array}$ & $0(0.0)$ & $1(3.8)$ & $4(15.4)$ & $6(23.1)$ & $15(57.7)$ \\
\hline
\end{tabular}

Source: Questionnaire data (2021)

Table 4.2 demonstrates teachers' responses on influence of ICT in teaching and learning process in secondary schools found in Misungwi district. Findings show that 38.5 percent of participants strongly agreed that applications of computers in teaching and learning in schools make lessons more effective, 50.0 percent agreed and 11.5 percent were moderate. Based on these findings, the majority of participants ( 88.5 percent) agreed with statement that using computers as teaching and learning instructions make lesson more effective in public secondary schools. This result is similar to was presented by the majority of students (86.0 percent) who have also agreed that the use of ICT facilities such as computers during teaching and learning in public secondary schools makes lesson more effective.

This outcome was explored more in an interview, where one interviewee was quoted saying that;

For sure, we want our students to come to class and learn with their all heart so that they can perform well in their exams. I think what you discovered from teachers and students are all true because, computer in an ICT facility which can be used as a teaching tool because it motivates students to attend the classrooms for learning. So teachers can connect their computers with the projector, or for those schools with a computer room, students can be given a free time to read the lesson notes themselves direct from the computer ( Interviewee E, August 2021).

In addition to that, Table 4.2 shows that 69.2 percent of the participants have agreed that using Smartphone in classroom instruction makes the lesson more effective, 15.4 percent were moderate and 15.4 percent disagreed with the notion that using Smartphone in classroom instruction makes the lesson more effective. Based on findings, it is 
observed that majority of participants who participated in this study have agreed that the use of smart phones in classroom instruction facilitates and makes lesson more effective in secondary schools.

This result is consistent with the student's responses where 85.9 percent have agreed that using smart phones in classroom instruction makes the lesson more effective.

During interview, one of interviewee from secondary school E blamed that

Of course we don't have computers in our schools. Sometime we use smart phones instead of using computers for searching some important materials concerning a certain subject. This situation enables us to handle within the implementation of ICT integration and facilitate teaching and learning process. (Interviewee E, September 2021).

This outcome postulates that the implementation of ICT integration on teaching and learning in secondary schools in Tanzania specifically in Misungwi District is passing in trouble period. This is because the schools face with variety of challenges. PO-RALG in partnership with other education stakeholders should increase their efforts to provide and improve ICT infrastructures and resources in public secondary schools.

Likewise, Table 4.2 shows that 53.8 percent have strongly agreed that power point presentation facilitate teaching and learning process, 34.6 percent agreed and 11.5 percent were moderate. These findings revealed that majority of participants (88.4 percent) agreed that the use of PowerPoint presentations in the classroom setting facilitates the teaching and learning process.

One interviewee had this to say;

Using PowerPoint in teaching is very helpful because it simplifies the teaching and learning process. This is due to the fact that teachers can easily finish their syllabus in time because they don't consume much time in providing lesson notes to students. However, this teaching technique is effective only whith a manageable number of students in a class. This school has overcrowding classrooms so there is a need to add more classrooms if $\mathrm{ICH}$ needs to be fully integrated in teaching and learning (Interviewee E, August 2021)

Furthermore, secondary school teachers were asked to rate their agreement level with the statement which states that using digital divide in the classroom, influences teaching and learning methods and modes of instruction. The study findings indicates that 77.0 percent of participants agreed that digital divide in the classroom influences teaching and learning methods and modes of instructions, while 3.8 percent indicates moderate and 19.2 percent of participants disagreed that the use of digital divide in classroom influences teaching and learning methods and modes of instructions.

Furthermore, Table 4.2 shows that 61.5 percent of the respondents have strongly agreed that ICT based teaching and learning, improves academic excellence in secondary schools, 19.2 percent agreed and 19.2 were moderate. These findings revealed that majority of participants (80.7 percent) agreed that ICT based teaching and learning in classroom settings improves students' academic excellence.

One interviewee was quoted adding that,

ICT in education is very important in ensuring effective teaching and learning process. Students and teachers can use internet for searching teaching and learning materials. It gives chance for students to get deep information about a certain topic taught in a class, students can connect with other students worldwide and learn from each other. So in general, ICT in education can help to improve learners' academic performance (Interviewee F, Sept. 2021).

Moreover, Table 4.2 shows that 80.8 percent of the respondents have agreed that internet sources in school environment increases the accessibility of more teaching and learning materials in schools, 15.4 percent were moderate and only 3.8 percent disagreed that internet sources in school environment improves the accessibility of teaching and learning materials. The findings revealed that majority of secondary school teachers in Misungwi district agreed that internet sources are very important facility that schools must have in order to access the teaching and learning materials. This finding resemble the finding of a questionnaire from students that showed that 57.8 percent of students have agreed that internet service in school settings helps to improve accessibility of teaching and learning materials in public secondary schools.

During interview, researcher asked one of participants from secondary school D who replied that

As a head of school in collaboration with the chairperson of the school board in this school, we are struggling to find a sponsor for the construction of the computer room as well as construction of 
Wi-Fi for internet service around the school environment. If this happens, it will facilitate the accessibility of teaching and learning materials on internet and the implementation of ICT integration at all will be effective (Interviewee D, September 2021)

These findings match with the study done by Demici (2009) in Turkey who revealed that internet service such as GIS software and hardware were very important determinants to the successful of ICTs integration and facilitate the accessibility of teaching and learning materials in geography lessons. This result implies that the availability of strong internet service such as Wi-Fi software in school environments could have a positive influence on implementation of ICTs integration on effective teaching and learning in public schools in Tanzania. If this service is available adequately, it could facilitate the implementation of schools programs and provision of quality education.

\section{CONCLUSIONS AND RECOMMENDATIONS}

Based on the findings of this study, it is clear that ICT integration in public secondary schools in Tanzania have several influences to the effectiveness of teaching and learning process. The study recommends that government and other education stakeholders should ensure that ICTs infrastructures must be strengthened. This must go hand in hand with the construction of computer rooms in schools; computers and projectors must be available in schools, strong internet signal, and stable electricity power. This could facilitate the effective implementation of ICT in public secondary schools and hence improvement of teaching and learning process. The study also recommends that the government should provide in-service training to teachers concerning the ICT in education to ensure that they have the needed knowledge and skills. Also, the study was conducted in public secondary schools; then the researcher recommends a similar study be conducted in public primary schools to discover the situation of ICT integration in education in this level of education.

\section{REFERENCES}

[1] Alcardo, A. B, Edvin J. K, Camilius S, George K,\& Noel M.(2015). Exploring Students' Skills and Attitudes on Effective Use of ICTs: Case Study of Selected Tanzanian Public Secondary Schools. Universal Journal of Educational Research 3(6): 407-425.

[2] Ayoub K, Petra F and Joke V. (2015).Factors Affecting Teachers' Continuation of Technology Use in Teaching. Educational Information Technology 21:1535-1554.
[3] Ayoub K. (2014).Access, Use and Perceptions of Teachers and Students towards Mobile phones as a Tool for Teaching and Learning in Tanzania. Educational Information Technology 19(1), 115 - 127

[4] Bryman, A. (2012). Social Research Methods. Oxford: Oxford University Press.

[5] Brayman, A. \& Bell, E. (2007).Social research methods $\left(3^{\text {rd }}\right.$ ed). New York: Oxford University Press.

[6] Chapelle, C. (2011). Computer Applications in Second Language Acquisition: Foundations for Teaching, Testing and Research. Cambridge: Cambridge University Press.

[7] Creswell, J. W., \& Plano Clark, V. L. (2011).Designing and conducting mixed methods research $\left(2^{\text {nd }}\right.$ Ed.). Thousand Oaks, CA: Sage Publications, Inc.

[8] Creswell, J.W. (2014).Education research: Planning conducting and evaluating qualitative and quantitative research $\left(5^{\text {th }} \mathrm{ed}\right)$. Boston, MA: Pearson Education.

[9] Demirci, A. (2009). How do Teachers Approach New Technologies: Geography Teacher's.Attitudes towards Geographic Information Systems (GIS).European Journal of Educational Studies, 1(1), 1-9.

[10] Ghavifekr, S. \&Rosdy, W. A. W (2015).Teaching and learning with technology; Effectiveness of ICT Integration in Schools.IJSRES, 1 (2), $175-191$.

[11] Grabe, M., \&Grabe, C. (2007). Integrating Technology for Meaningful Learning. New York: Houghton Mifflin.

[12] Hermans, R., Tondeur, J., van, B. J., \&Valcke, M. (2008).The impact of primary school teachers' educational beliefs on the classroom use of computers. Journal of Computers \& Education, 51(4), 1499-1509.

[13] Isaacs, S (2007).Survey of ICT and Education in Africa: Botswana Country Report. Retrieved From www.infodev.org

[14] Kamal, M. \& S. Qureshi, (2009)."Sustaining the Growth of Micro-enterprises that Adopt Information and Communication Technologies". Proceedings of the Second Annual Workshop on Global Development. Phoenix December, http://www.globdev.org/?q=node/71

[15] Sun, A., \& Chen, X. (2016). Online Education and its effective practice: A research review. Journal of Information Technology Education. Research, 15, 157-190

[16] Kombo, D. K., \& Tromp, L. A. (2006). Proposal and Thesis Writing: An Introduction. Nairobi: Pauline Publications Africa.

[17] Kothari, C. R (2004).Research Methodology, Methods and Techniques. Delhi, India: New Age International Publisher.

[18] Kothari, C. R., \&Garg, G. (2014).Research methodology: Methods and techniques ( $3^{\text {rded.) }}$ London: New Age International Publisher.

[19] Luhamya, A, Bakkabulindi, P.E.K \&Muyinda P. B (2017). Integration of ICT in Teaching and Learning: A Review of Theories. Makerere Journal of Higher Education, 9(1), 2136

[20] Mangesi, K, (2007).Survey of ICT and Education in Africa: Ghana Country Report. Retrieved From www.infodev.org

[21] Malakia, J., \&Cloneria, J. (2018). Teachers' perception on the use of ICT in Teaching and Learning: A Case of Namibian Primary Education. University of Eastern Finland. 
[22] Ministry of Education and vocation training (2014).Tanzania Education and Training Policy 2014.Government Printer, Dar Es salaam, Tanzania.

[23] Muchiri, K. P. (2012). Challenges Influencing the Implementation of Free Secondary Education in Kangema District, Muranga County, Kenya.(Masters Dissertation, Department of Education Management, Policy and Curriculum Studies, Kenyatta University)

[24] Mugenda, O. M., and Mugenda, A. G. (2003).Research Methods. Nairobi, Kenya: African Centre for Technology Studies (ACTS)

[25] Placidius N. (2014).Teachers' Attitudes towards the Use of Information Communication Technology (ICT) as a Pedagogical Tool in Secondary Schools in Tanzania: The Case of Kondoa District. International Journal of Education and Research 2(2), ISSN: 2360 - 994X

[26] Stephanie, E. (2003). Slovin's formula. Sampling Techniques. Hougton-Mufflin: New York, USA.

[27] Sweeney, T. (2016).A convergent parallel mixed-methods investigation into the roles of mindfulness in moderate to severe persistent depression. Doctoral Thesis, University of Nottingham.

[28] Paschal, M. J., \& Mkulu, D. G. (2020). Online classes during covid-19 pandemic in higher learning institutions in Africa. Global Research in Higher Education, 3(3). doi: 10.22158/grhe.v3n3p1

[29] Teo, T. (2008). Pre-service teachers' attitudes towards computer use: A Singapore survey. Australasian Journal of Educational Technology, 24(4), 413-424.

[30] Williams, C. (2007). Research Methods. Journal of Business \& Economic Research, 5(3): 65-72 